\title{
USA:n yliopistot ja poliittinen sopivuus
}

Poliittinen sopivuus ("Political Correctness" eli PC), edistyksellisyyden nimissä harjoitettu ajatusterrori, on vuoden 1991 termi USA:n yliopistokampuksilla. Valtakunnalliset huippulehdet kuten Newsweek ja Wall Street Journal ovat verranneet vasemmistolaista hegemoniaa kampuksilla ruskeiden paitojen voimaan ja mccarthyismiin. Eräänlainen huipentuma tähänastisissa tapahtumissa oli presidentti Bushin maaliskuussa, Michiganin yliopiston kevään valmistujaisjuhlallisuuksissa, pitämä puhe, jossa hän totesi "inkvisition", "sensuurin" ja "kiusaamisen" voittaneen ajatusten voiman kampuksilla ja vaati sananvapauden saattamista takaisin voimaan.

Kampuksilla kuulee myös toisenlaista puhetta. Tämän vuoden meteliä PC:stä kuvataan huolellisesti valmistelluksi kampanjaksi, jonka takana ovat tietyt oikeistolaiset yliopistopiirit. Pohjoiskalifornialainen vasemmistolainen aikakauslehti Mother Jones paljastaa viime syys-lokakuun numerossaan yksityiskohtaisesti, miten "National Association of Scholars" -niminen järjestö on valtakunnan lehdistön PC-aiheisten artikkeleiden taustalla. Vastajärjestö 'Teachers for a Democratic Culture" on jo perustettu johtamaan puolustushyökkäystä.

PC ei ole kuitenkaan täysin sattumalta syntynyt teema. Sen taustalla on todellisia ongelmia, monessakin mielessä.

Saavuin USA:han vierailevana tutkijana tammikuussa 1991. Yliopistoni, University of California Santa Cruz, kuuluu länsirannikon pieniin yliopistoihin, joilla on radikaali maine. Yliopisto on jakautunut kahdeksaan collegeen, jotka ovat monitieteisiä ja teemoittain orientoituneita. Oman collegeni erikoisaloja ovat muun muassa feministisesti orientoitunut tutkimus, seksuaalisten vähemmistöjen tutkimus sekä monikulttuurisuus.

Tammikuussa osallistuin ensimmäisiin tilaisuuksiin, joihin kuuluivat naisten keskuksessa järjestetty Persianlahden sodan vaikutusta opetukseen koskenut keskustelu ja muutama vierailuluento. Hämmästyin poliittista tunnelmaa. Se oli yllättävän polarisoiva ja intensiivinen. Suomessa on yliopistopiireissä viimeistään viiden viime vuoden aikana totuttu mustavalkoisten vastakkainasettelujen epäilyyn. "Edistyksen" käsite on muuttunut "edistyksellisissä" piireissä niin ongelmalliseksi, että sen esiintyminen tämän lehden nimessä on lähinnä historiallinen dokumentti. USA:n länsirannikon yliopistoissa edistyksellinen liike on edelleen vahvasti olemassa, ainakin ideologisesti. Siihen kuuluvat niin marxilaiset kuin ekologisia arvoja korostavatkin, sekä feministit, homot, lesbot, rotuennakkoluulojen vastustajat, vähemmistökulttuurien edustajat ja rauhan puolustajat. Sen vastustaja on "mainstream"-amerikkalainen valkoinen miesmaailma, rasismi, homofobia ja kaupallinen kulttuuri ja imperialismi.

Kalifornialaiset ovat yleensä erittäin huumorintajuisia, mutta näissä asioissa he ovat yllättävän vakavia. Voi olla että ulkopuolisena en kykene arvioimaan täysin tarkasti, mutta sain sen vaikutelman, että kampuksella on parempi tulla selvästi yhdistetyksi edistyksellisyyteen. On varottava poliittisesti epäsopivaa 
esiintymistä. Ei siksi, että se aiheuttaisi todella pahoja ongelmia, väkivaltaa tai menetettyjä työpaikkoja, vaan paljon hienovaraisemmista syistä. Voidaan pikemminkin puhua eräänlaisista eksklusiivisista käytännöistä. "Me" ja "he" erotetaan ennemminkin katseilla ja äänensävyillä. Tulin esimerkiksi nopeasti siihen tulokseen, että provokatiivinen hameiden käyttö ei olisi täällä sopiva poliittinen ele. Ja kynnet on parempi jättää lakkaamatta.

Tilaisuuksissa käytetyissä puheenvuoroissa oli tiettyä "tunnustuksellisuutta" ja näyttämisen makua, ja vaikka solidaarisuus ja yhteisyys onkin usein niin ihanaa, se myös painostaa. Sain myös sen käsityksen, että varsinkin opiskelijat mutta myös monet opettajat ovat hyvin vaativia sen suhteen, että opetus on välittömästi "maailmaa parantavaa", oikeita käsityksiä esittävää ja myös hengeltään tunnustuksellista.

Omasta puolestani en pidä lainkaan tällaisesta fundamentaalisuutta lähentelevästä tunnelmasta, ja tätä, hieman epämiellyttävää, kokemusta vasten puhe PC:stä ei vaikuttanut aivan tuulesta temmatulta. Näyttää siltä, että aika lailla poliittista puhdasoppisuutta, intoilua ja happamuutta on liikkeellä.

PC-keskustelussa on kyse kuitenkin myös paljon enemmästä. Hermostumisen taustalla on se tosiasia, että USA:n yliopistomaailma on sitten vuoden 1968 muuttunut lähes pelkästään valkoisten heteroseksuaalisten miesten maailmasta alueeksi, jossa yli puolet opiskelijoista ja jo suuri osa opettajistakin on jotakin muuta: naisia, mustia, chicanoja, aasialaisia, etujensa puolesta näkyvästi esiintyviä homoseksuaaleja, vammaisia jne. Aiemmin etuoikeutetut ryhmät ovat menettäneet etujaan ja ovat turhautuneita, ja uudet ryhmät ovat epävarmoja oikeuksistaan.

Esimerkiksi Berkeleyn vuonna 1968 kapinoivalla kampuksella oli opiskelijoista 2,8\% mustia ja 1,3\% chicanoja eikä aasialaisia ollut lainkaan. Tällä hetkellä nämä kolme ryhmää muodostavat yhdessä $50 \%$ opiskelijoista.

Rodullinen ja kulttuurinen moninaisuus on osittain tulosta tietoisesta politiikasta, jolla yliopistotasoisen koulutuksen saaneiden joukko on pyritty saamaan lähemmäs väestön yleistä rotu- ja sukupuolirakennetta. 1970-luvulta lähtien eri muodoissa harjoitettu, historiallisia epäoikeudenmukaisuuksia tasaava toiminta tunnetaan nimellä affirmative action. Sen mukaisesti yliopistot voivat ottaa sisäänpääsykokeissa huomioon eri väestöryhmien tasapainon opiskelijakunnassaan. Käytännössä tämä tarkoittaa sitä, että mustat (joita on poliittisesti sopivampaa kutsua afrikan-amerikkalaisiksi), chicanot eli latinot (Kaliforniassa lähinnä meksikolaiset), Amerikan alkuperäisasukkaat (intiaanit) ja aasialaiset pääsevät pienemmillä pistemäärillä sisään yliopistoihin.

Tämä aiheuttaa jatkuvaa katkeruutta osassa valkoista opiskelijakuntaa ja osassa heidän vanhempiaan, erityisesti poliittisessa oikeistossa. Se aiheuttaa myös eri rodullisten ryhmien välien kiristymistä kampuksilla. Eikä se ilmene pelkästään valkoisten katkeruutena, vaan myös suosittujen epävarmuutena siitä, ovatko he ansainneet paikkansa. 
Kampuksilla opetellaan elämään rodullisessa ja kulttuurisessa moninaisuudessa, mikä on usein vaikeaa. Ongelmat lähtevät siitä, tuleeko kampusradiossa soittaa rappiä, salsaa vai countrya, ja jatkuvat äärimmillään helposti heitettyinä "rasisti"-syytöksinä. Kirkaskatseinen, usein etuoikeutetusta asemastaan tietämätön valkoinen amerikkalaisnuori ei voi ymmärtää, miksi musta opiskelijatoveri on epäluuloinen, vihainen ja omiensa luokse eristäytyvä, vaikka hän itse on täysin ennakkoluuloton. Mustien historia tässä maassa on kuitenkin niin armoton, että sen aiheuttamia epäoikeudenmukaisuuksia ei korjata hetkessä. Tosiasiassa USA on edelleen erittäin rasistinen, ja mustien sosiaalinen asema on kaiken kaikkiaan 1970-luvulta huonontunut. Yliopistot ovat poikkeus yleisessä epäoikeudenmukaisuudessa rotujen välillä, eivätkä niihin tulevat mustat nuoret aina ole varmoja siitä missä heidän paikkansa on.

Tilanne on kuitenkin muuttunut siitä millainen se oli vielä viisikymmenluvulla, jolloin Mother Jonesissa kirjoittava musta juristi Roger Wilkins tuli yliopistoon ainoana mustana vuosiluokastaan. Hänen opiskeluaikanaan ei opetettu mitään Afrikasta, ei orjista, ei orjien panoksesta maalle, eikä heidän jälkeläistensä vaikeuksista elämänsä järjestämisessä. Hänen yliopistossaan vallitsi kapea valkoisten miesten hegemonia, jossa hän oli hyvin nöyrä ja varovainen muukalainen. Nykyinen värillisten opiskelijoiden joukko on suurempi, tietoisempi omasta historiastaan ja omaa ryhmäänsä kohdanneista epäoikeudenmukaisuuksista. Se on samanaikaisesti varautunut ja hyökkäävä, epävarma ja arka loukkaantumaan poliittisesti.

Eri rotu- ja kulttuuriryhmien suhdetta valkoiseen anglokulttuuriin leimaa ristiriita sen välillä, tuleeko korostaa omaa identiteettiä vai tasavertaisuutta valkois- ten kanssa. Reaktiot kampuksilla heilahtelevat äärimmäisyydestä toiseen. Välillä vähemmistöryhmät edistävät tietoisuutta omasta erityisyydestään ja eristäytyvät valkoisista, välillä ne vaativat samanarvoista kohtelua. Leimallista on, että valkoisten ei tarvitse eristäytyä ollakseen tietoisia omasta erityisyydestään, kaikki tukee edelleen heitä. Tilanne on täsmälleen se, mitä Lyotard kuvaa käsitteellään différend: jollekin on tehty vääryyttä, ja se on tehty niin, että uhrilta on samalla viety mahdollisuus todistaa vääryys sillä kielellä mitä käytetään.

Sama koskee naisten asemaa miesten kulttuurissa, ja tunnelmat kampuksilla ovat samankaltaiset naisten ja miesten välisen kulttuurieron suhteen. Jotkut naisryhmät eristäytyvät ja suhtautuvat vihamielisesti miehiin. Esimerkiksi radikaaliin lesbokulttuuriin on äärimmäisen avoimella mielelläkin varustetun miehen vaikea päästä sisään. Ehkä ei kuitenkaan aivan yhtä mahdotonta kuin naisten niihin, vain miehille tarkoitettuihin yliopistoklubeihin, joista yhteen presidentti Bush vanhana Yalen yliopiston kasvattina edelleen kuuluu.

"Rasismi", "seksismi" ja "homofobia"-syytökset ovat poliittisen sopivuuden suhteen pahimpia, mitä yliopistomaailmassa voi päälleen saada, ja moni var- 
masti yrittää kaikin keinoin välttää niitä. On myös varmasti niitä, jotka käyttävät tätä hyväkseen ja syytävät syytöksiä milloin se on heidän etujensa mukaista. Ja on myös niitä, jotka muodostavat poliittisesta puhdasoppisuudesta joustamattoman doktriinin ja vartioivat sen toteutumista yliopistoissa.

Vaikka PC-puheiden takana on osittain pelko siitä, että värilliset, vähemmistöt ja naiset valtaavat yliopistot, valtasuhteet eivät kuitenkaan saata valkoisia miehiä tällä hetkellä mitenkään uhanalaiseen asemaan. Vertaukset toisaalta vasemmistolaisten, naisten ja näkyvien vähemmistöjen toiminnan ja toisaalta natsien ja mccarthyismin välillä ovat hätkähdyttävän liioiteltuja: kyse ei ole valtion ja oikeuslaitoksen takaamasta terrorista, väkivaltaisista koneistoista tai systemaattisesti tuhotuista urista.

Esimerkiksi Berkeleyn opettajakunnasta on edelleen valkoisia 88,6 \% ja miehiä 83,9\%. 1960-luvulta jatkuneen maineensa perusteella yliopiston pitäisi olla radikaali, mutta vasemmistolaisten opettajien löytäminen on vaikeaa. UCLA:n koko valtakunnan yliopistollisesta opettajakunnasta tekemän tutkimuksen mukaan vain $4,9 \%$ ilmoittautuu vasemmistolaisiksi. $17,8 \%$ on omasta mielestään konservatiiveja ja loput eli suurin osa liberaaleja tai maltillisia. Roger Wilkins kirjoittaa: "Jotkut 18-vuotiaat ovat kyllä tiukkoja poliittisissa arvioinneissaan, mutta olisi loukkaus näitä agitoijia kohtaan sanoa, että heidät on ohjelmoinut PC-tietoinen vasemmistolaisten opettajien kaaderi."

Osallistuin maaliskuussa yliopistossani järjestettyyn kongressiin, jonka yksi osa oli paneelikeskustelu PC:stä. Osallistujina oli kaksi valkoista naista, Tyynenmeren saarilta kotoisin oleva mies ja thaimaalaista syntyperää oleva nainen, kaikki yliopiston opettajia.

Molempien valkoisten naisten idea oli kääntää oikeistolainen hyökkäys hyödylliseksi itsekritiikiksi. Toinen puhui siitä, miten hän on kyllästynyt opettamaan pelkästään feminismiin suoranaisesti liittyviä aiheita, poliittisesti välittömästi tärkeitä kysymyksiä ja pelkästään naisten kirjoittamia tekstejä, ja miten hän tuntee, ettei voi tällä tavalla antaa parastaan oppilailleen. Tämä poliittisen teorian spesialisti ja feministi kertoi itse vaikuttuneensa aikoinaan eniten Platonin lukemisesta ja haluavansa mieluummin antaa opiskelijoille jotakin siitä mikä on mahdollistanut hänen nykyisen yhteiskuntakriittisen ajattelunsa.

Toinen valkoinen nainen kertoi siitä miten oli, opiskelijoiden vastustuksesta huolimatta, halunnut käsitellä luennoillaan uskonnollisen fundamentalistisesti ajattelevan bestseller-kirjailijan käsityksiä naisista ja tunkeutua, eläytyen, niin syvälle hänen ajatusmaailmaansa kuin mahdollista. Vaikka nämä näkemykset eivät olekaan poliittisesti korrekteja (opiskelijat olivat kieltäytyneet ostamasta kirjaa), ne opettavat jotakin. Ja on myös tärkeä osata analysoida, miksi toiset ajattelevat eri tavalla, hän totesi. 
Värillisten osanottajien puheenvuorot olivat kuin toisesta maailmasta. Heidän puheenvuoronsa asettivat pelkällä ilmaisutavallaan valkoisten naisten puheenvuorot aivan uuteen valoon: sellaisiksi, jotka esitetään hyvin turvallisesta asemasta. Näiden puheenvuorojen pääviesti oli pelko, ja ne olivat hyvin haavoittuvia, paljaita ja toisaalta emotionaalisesti vahvoja. Ne esitettiin kuin repaleisena suojakilpenä PC-hyökkäystä vastaan. Niiden lähtökohta oli, että PChyökkäys asettaa vaakalaudalle sen vähän, mitä toisista kulttuureista tulijoilla tällä hetkellä on yliopistoissa saavutettavana.

Poliittisesti oikeamielinen yleisö reagoi niin kuin pitääkin: se buuasi valkoisille naisille ja suhtautui äärettömän suojelevasti ja kannustavasti värillisiin esiintyjiin.

Platonin opettamisesta puhunut nainen sai niskaansa varsinaisen ryöpyn hyökkäyksiä. (Platon on ensinnäkin mies, ja toiseksi yksi porvarillisista pääideologeista, jota ei ole poliittisesti sopivaa opettaa.) - Minuun teki suuren vaikutuksen se, että vihaisen ja vaativan poliittisesti oikeassa olevan joukon edessä tämä nainen piti oman kantansa - sen vuoksi että se oli hänen mielestään oikea.

Tilaisuus jätti minut omien ristiriitojensa kannalta paradoksaaliseen tilaan: olin yhtä aikaa sitä mieltä, että yleisö oli positiivisessa mielessä "poliittisesti oikeassa" ja että nainen, joka puolusti Platonin opiskelemista, oli myös oikeassa. Rodullisten ja kulttuuristen epäoikeudenmukaisuuksien korjaaminen on USA:laisessa maailmassa äärettömän tärkeä tehtävä, ja siitä on oltava tietoisia joka tilanteessa. On selvä, että PC-keskustelussa on kyse vakavasta hyökkäyksestä tätä politiikkaa vastaan, eikä sitä pidä unohtaa. Silti on erittäin tärkeää, että jokainen tekee omat moraaliset päätöksensä parhaan arviointikykynsä mukaan eikä sen mukaan, näyttääkö se poliittisesti oikealta. Olen tietenkin itse myös sitä mieltä, että klassiseen filosofiaan perehtyminen on lähes tilanteessa kuin tilanteessa radikaalia ja käytännöllistä, ja on velvollisuus opettaa sitä, mitä pitää parhaana.

Poliittinen tila on alati liikkuva ja sen muutoksille on oltava herkkä, jos haluaa arvioida. Alistettu vähemmistö voi hetkellisesti muuttua alistavaksi enemmistöksi tai alistavaksi vähemmistöksi. Silmänräpäyksellisen nopea reagointi lokaaleihin epäoikeudenmukaisuuksiin ei saa jättää varjoonsa pitkän tähtäyksen pyrkimyksiä korjata suuria epäoikeudenmukaisuuksia. Mutta kun suuria epäoikeudenmukaisuuksia korjataan, on oltava reseptiivinen niille uusille epäoikeudenmukaisuuksille, joita uusista käytännöistä koko ajan syntyy.

PC-keskustelun nostamaa ajatusta käyttäytymisestä poliittisissa konfliktitilanteissa ei kannata väheksyä. Oma yliopistollinen aatehistoriamme osoittaa, että on helppo olla mukana oikeassa olevassa ryhmässä ja muodostaa eksklusiivisia käytäntöjä.

On ikävää, jos yliopistossa leikitään niin kuin tuhmat lapset hiekkalaatikolla: 
tönitään, kiusataan ja osoitellaan sormella. - Vielä ikävämpää kuitenkin on, jos presidentit suhtautuvat yliopistoihin kuin olisivat hiekkalaatikolla leikkivien lasten isiä, joiden pitää tulla apuun kun omia poikia kiusataan.

Silloin kun kyse ei ole yhteiskunnan muiden rakenteiden takaamasta syrjinnästä ja sorrosta, yliopisto on ympäristö, jossa eksklusiiviset käytännöt on mahdollisuus purkaa ja jossa sensitiivisyys epäoikeudenmukaisuuksia kohtaan on yleensä suuri. Yliopistoissa, myös USA:laisissa yliopistoissa, näyttää aina silloin tällöin muodostuvan oikeudenmukaisuutta koskevissa kysymyksissä kantoja, jotka ovat niin uusia ja herkkiä ja niin suuressa ristiriidassa vallitsevien suhteiden kanssa, että ne vaativat suojakseen vihamielisesti ulospäin suuntautuvia piikkejä ja joskus naurettavuuteen asti meneviä sääntöjä. Yleensä ne saavat myöhemmin muita muotoja, ja muuttavat yhteiskuntaa johonkin suuntaan. Silloin kun tällaiset liikkeet ajoittain muuttuvat vaativiksi, tukahduttaviksi fundamentalistisiksi voimiksi, itseään kunnioittava yliopistoihminen ei tietenkään jää niiden jalkoihin, vaan arvioi itse oman parhaan kykynsä mukaan. Jos haluamme uskoa yliopistoihin kriittistä ajattelua ylläpitävinä laitoksina, niin kuin edelleen haluaisin tehdä, niin tähän on luotettava: sitä yliopistojen ainakin pitäisi meille opettaa!

Santa Cruzissa, Kaliforniassa syyskuussa 1991

Tuija Pulkkinen 